\title{
The age of mantle lithosphere on the northernmost margin of the Central Orogenic Belt, North China Craton
}

\author{
Jingao Liu ${ }^{1}$, Roberta L. Rudnick ${ }^{1}$, Richard J. Walker ${ }^{1}$, Shan Gao ${ }^{2,3}$ and Fu-yuan Wu ${ }^{4}$ \\ ${ }^{1}$ Department of Geology, University of Maryland, College Park, MD 20742, USA \\ ${ }^{2}$ Faculty of Earth Science, China University of Geosciences, Wuhan 430074, China \\ ${ }^{3}$ State Key Laboratory of Continental Dynamics, Geology, Northwest University, Xi'an 710069, China \\ ${ }^{4}$ State Key Laboratory of Lithospheric Evolution, Institute of Geology and Geophysics, Chinese Academy \\ of Sciences, P.O. Box 9825, Beijing 100029, China
}

The North China Craton (NCC) is one of the major Archean cratons in eastern Eurasia, bounded by the Xing-Meng Orogen to the north and the Qinling-DabieSulu Orogen to the south (Fig. 1). The NCC is divided into three blocks: the Western Block, the Eastern Block and the intervening Central Orogenic Belt (COB) (Fig. 1). The NCC has been extensively studied over the past ten years, as a wealth of observations suggest that the thick, cold and refractory Archean lithospheric keel that existed beneath the Eastern Block at least through the Ordovician was removed and replaced by thin, hot and relatively fertile lithospheric mantle during the Mesozoic-Cenozoic.

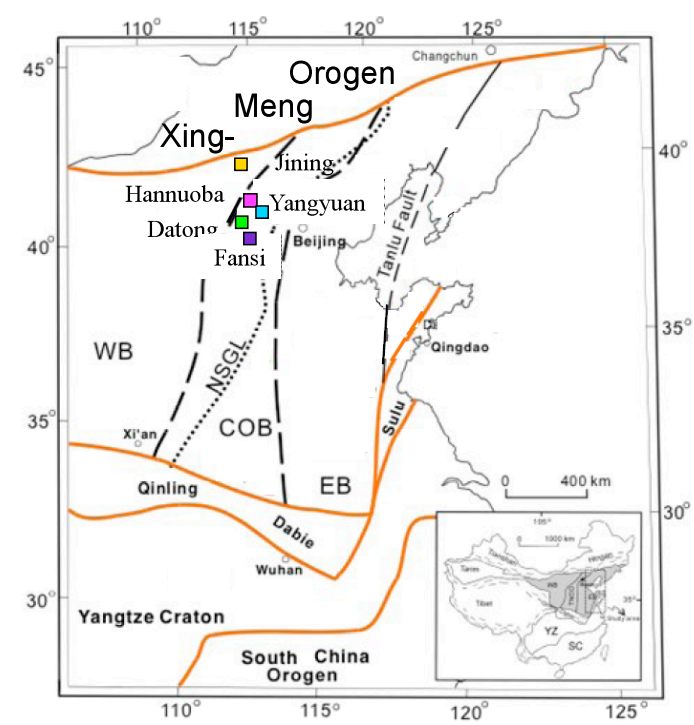

Fig. 1. Sketch map of the NCC with mantle xenolith localities in and near the COB (colored squares).

In the northern $\mathrm{COB}$, several localities of Tertiary alkali basalts carry mantle xenoliths: Hannuoba, Yangyuan, Datong and Fansi. In addition, the Jining locality occurs in Inner Mongolia at the northern boundary of the NCC. Previous Os isotope studies of xenoliths from the $\mathrm{COB}$ have reported model ages ranging from $\sim 2 \mathrm{Ga}$ at Hannuoba (Gao et al., 2002; X. $\mathrm{Xu}$ et al., 2008), which lies to the west of the NorthSouth Gravity Lineament (NSGL), to Archean and Paleoproterozoic ages beneath the more southerly Yangyuan locality (Y-G. Xu et al., 2008).
These ancient ages demonstrate that old lithospheric mantle currently underlies the COB, consistent with an interpretation that the NSGL is the westernmost demarkation of Mesozoic-Cenozoic thinning. Current debate regarding the $\mathrm{COB}$ focuses on: 1) whether any Archean lithosphere is preserved here (Y-G. Xu et al., 2008), and 2) whether the predominant $\sim 2$ Ga ages recorded at Hannuoba reflect replacement of original Archean lithosphere by new lithosphere at that time (Gao et al., 2002) or complete overprinting of Archean lithosphere (X. Xu et al., 2008). There seems to be agreement that whatever the process involved with producing the $\sim 2$ Ga ages, it was likely associated with collision between the Eastern Block and Western Block of the NCC, which occurred about this time (Zhao et al., 2000).

In order to investigate these issues further, we have measured major and highly siderophile element abundances, and Os isotopic compositions of peridotite xenoliths from the Yangyuan and Jining localities.

\section{Petrology and bulk rock compositions}

Peridotite xenoliths from Yangyuan and Jining are mostly spinel lherzolites and harzburgites, similar to those from Hannuoba. Yangyuan peridotites are large and fresh, while Jining peridotites are small and moderately altered, producing at most a few grams of whole rock powder. Olivines from a total of 138 peridotites from the two localities have similar forsterite contents ( 88 to 92 , with a mode of $~ 90.5$ ) to those from Hannuoba (Fig. 2). These peridotites are, thus, less refractory than those carried in Ordovician kimberlites in the Eastern Block, which are fragments of Archean mantle lithosphere (Gao et al., 2002; Wu et al., 2006; Zheng, J.P., 1999). We selected suites of peridotites from each locality that span the entire range in Fo for our study. The Yanguyan peridotites follow a melt depletion trend on major element variation diagrams (Fig. 3). As a point of comparison, only a few samples overlap the composition of Archean cratonic Kaapvaal peridotite xenoliths (Fig. 3). In contrast, Jining peridotites scatter off the melt depletion trend, which likely reflects mineralogical bias resulting from the small sample sizes. 


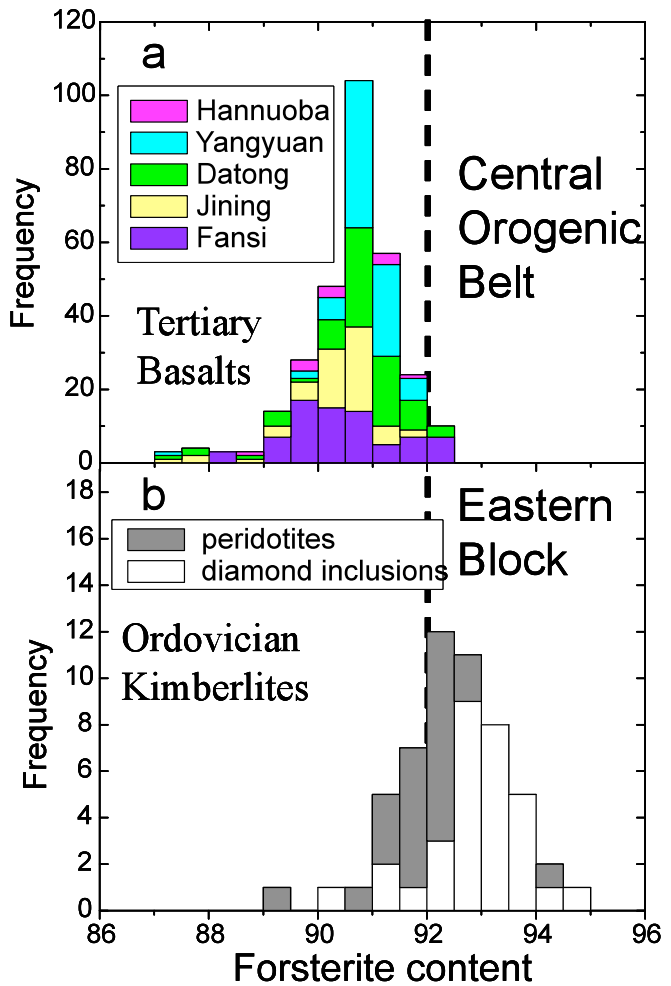

Fig. 2. Forsterite (mol $100 * \mathrm{Mg} /(\mathrm{Mg}+\mathrm{Fe}))$ content histograms for mantle peridotites and diamond inclusions. The vertical dash line is for a forsterite content of 92 . The data for $b$ are from Zheng, J.P. (1999).

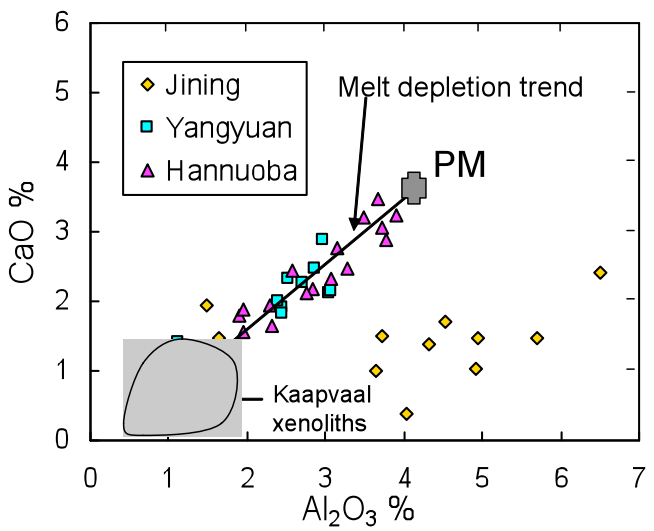

Fig. 3. $\mathrm{Al}_{2} \mathrm{O}_{3}$ vs. $\mathrm{CaO}$ in whole rock peridotites. PM: Primitive Mantle (McDonough and Sun, 1995).

\section{Rhenium and platinum group elements}

During mantle melting, Os, Ir and Ru typically behave compatibly, while $\mathrm{Pt}, \mathrm{Pd}$ and $\mathrm{Re}$ are normally incompatible. This is commonly reflected in chondritenormalized $\mathrm{Re}+\mathrm{PGE}$ patterns of melt residues with $\mathrm{Pt}$, $\mathrm{Pd}$ and Re becoming progressively depleted relative to $\mathrm{Os}$, Ir and $\mathrm{Ru}$ during melting. If peridotites experience secondary processes (e.g., melt-rock interaction, sulfide metasomatism), Pt, Pd and Re may, conversely, become enriched. Such processes, however, can also affect Os, Ir and Ru abundances, and even lead to changes in ${ }^{187} \mathrm{Os} /{ }^{188} \mathrm{Os}$.

Most Re+PGE patterns for Hannuoba xenoliths are similar to PUM (Becker et al., 2006). The positive correlation between $(\mathrm{Pd} / \mathrm{Ir})_{\mathrm{N}}$ and ${ }^{187} \mathrm{Os} /{ }^{188} \mathrm{Os}$ (Fig. 5b) suggests $\mathrm{Re}$ as the source of radiogenic Os. This is not consistent with overprinting of the Re-Os system, so these rocks appear to indeed be residues that formed during the Proterozoic.

Yangyuan peridotites are characterized by patterns that are more depleted in $\mathrm{Pt}, \mathrm{Pd}$ and $\mathrm{Re}$ than those of Hannuoba (Fig. 4a). The broadly positive correlations between $\mathrm{Al}_{2} \mathrm{O}_{3}$ or ${ }^{187} \mathrm{Os} /{ }^{188} \mathrm{Os}$ and $(\mathrm{Pd} / \mathrm{Ir})_{\mathrm{N}}$ define a melt depletion trend (Fig. 5), which apparently has not been significantly influenced by recent overprinting. All Yangyuan peridotites have relatively low Os concentrations (0.2-2.3 ppb). Osmium is depleted relative to $\mathrm{Ir}$ and $\mathrm{Ru}$, which is not observed in Hannuoba peridotites. In addition, the overall Re+PGE contents of Yangyuan peridotites are generally lower and more variable than those of Hannuoba peridotites. The cause of these depletions is unclear.

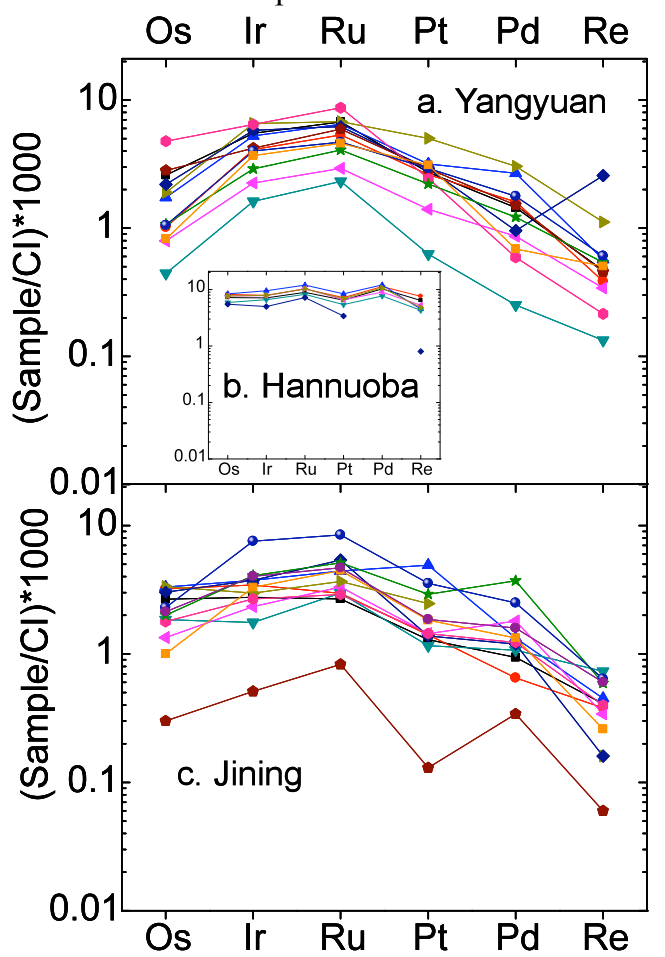

Fig. 4. CI normalized (x1000) Re+PGE patterns for peridotites from: a. Yangyuan ; b. Hannuoba (Becker et al., 2006); c. Jining.

Jining peridotites have Re+PGE patterns that are similar to the Yangyuan samples (Fig. 4c). They also have low Os concentrations and a negative correlation between Os concentrations and $(\mathrm{Pd} / \mathrm{Ir})_{\mathrm{N}}$. The positive correlation between $(\mathrm{Pd} / \mathrm{Ir})_{\mathrm{N}}$ and ${ }^{187} \mathrm{Os} /{ }^{188} \mathrm{Os}$ suggests that the characteristics of these patterns were established early, and that the Os isotopic system was likely not modified by relatively recent processes including alteration (Fig. 5b).

\section{Re-Os isotopic compositions}

During mantle partial melting, $\mathrm{Re}$ is normally moderately incompatible while $\mathrm{Os}$ is compatible, leaving the peridotite residue with low Re/Os ratios. Since $R e$ is mobile in peridotite xenoliths, especially during the transit of xenoliths to the surface, it is very rare to obtain Re/Os isochrons. Due to low Re/Os 
ratios, $\mathrm{T}_{\mathrm{RD}}$ model $\mathrm{Re}$ depletion ages are often calculated relative to the hypothetical PUM (Meisel et al., 2001) to constrain the timing of melt extraction. Since Al behaves similarly to Re during partial melting but is much less mobile, $\mathrm{Al}_{2} \mathrm{O}_{3}$ contents have been treated as proxies for $\mathrm{Re} / \mathrm{Os}$ ratios and indices of degree of melt extraction.

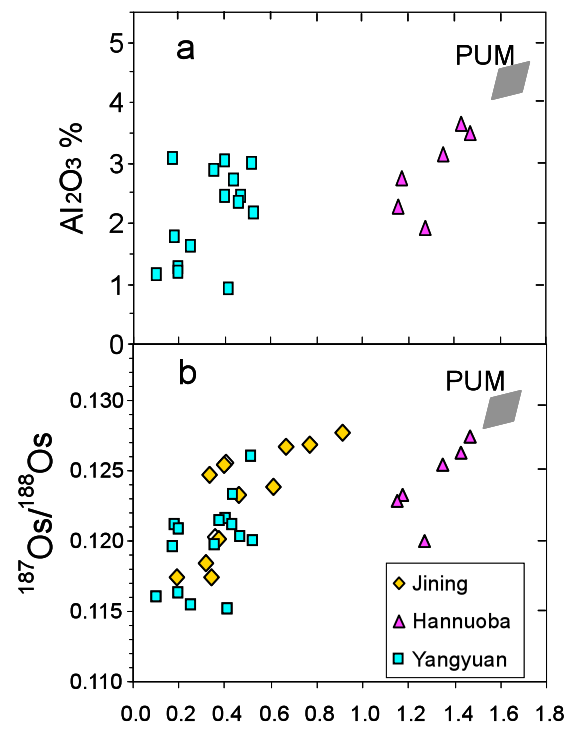

$(\mathrm{Pd} / \mathrm{lr})_{\mathrm{N}}$

Fig. 5. a. $\mathrm{Al}_{2} \mathrm{O}_{3}$ vs. $(\mathrm{Pd} / \mathrm{Ir})_{\mathrm{N}}$, b. ${ }^{187} \mathrm{Os} /{ }^{188} \mathrm{Os}$ vs. $(\mathrm{Pd} / \mathrm{Ir})_{\mathrm{N}}$. PUM: Primitive Upper Mantle from Becker et al. (2006).

The Yangyuan peridotites have subchondritic ${ }^{187} \mathrm{Os} /{ }^{188} \mathrm{Os}$, ranging from 0.115 to $0.126\left(\mathrm{~T}_{\mathrm{RD}} \leq 2.0\right.$ $\mathrm{Ga}$, and overlapping with those of Hannuoba peridotites (Gao et al., 2002). None of the samples we measured had ${ }^{187} \mathrm{Os} /{ }^{188} \mathrm{Os}$ with Archean model ages, as reported by Y-G. Xu et al. (2008). To consider this further we acquired the most depleted samples from Y$\mathrm{G}$. Xu. Our results are consistently more radiogenic than the published and are not consistent with Archean melt extraction.

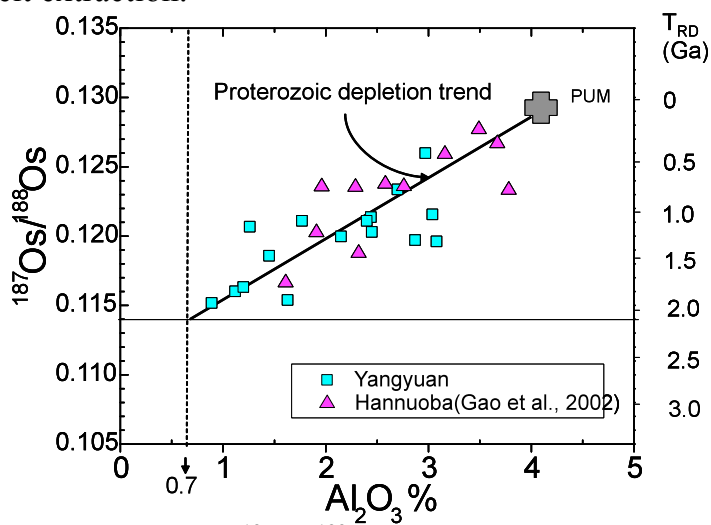

Fig. 6. Whole rock ${ }^{187} \mathrm{Os} /{ }^{188} \mathrm{Os}$ ratios vs. $\mathrm{Al}_{2} \mathrm{O}_{3}$ and model ages.

Both Yangyuan and Hannuoba samples define good positive correlations between ${ }^{187} \mathrm{Os} /{ }^{188} \mathrm{Os}$ and $\mathrm{Al}_{2} \mathrm{O}_{3}$ contents, consistent with ancient melt depletion trends (Fig. 6). Using the methods of Handler et al. (1999), these trends suggest a melt depletion age of $\sim 2 \mathrm{Ga}$.
The Jining peridotites have chondritic to subchondritic ${ }^{187} \mathrm{Os} /{ }^{188} \mathrm{Os}$, $(0.117$ to 0.128$)$, with $\mathrm{T}_{\mathrm{RD}}$ model ages as low as $1.8 \mathrm{Ga}$. Thus, this portion of the lithospheric mantle evidently underwent melting at roughly the same time as mantle underlying Hannuoba and Yangyuan.

In summary, Yangyuan and Jining peridotites do not appear to have experienced recent overprinting of the Os isotopic system. As such, they are similar to Hannuoba peridotites. Osmium model ages of bulk samples suggest that these peridotites underwent a dominant melt depletion event during the Paleoproterozoic. This, in turn, may indicate that mantle lithosphere formed during this period of time in the northern COB. Given the Archean age of the overlying crust, these results point to replacement of the original Archean lithospheric mantle during the Paleoproterozoic, likely associated with the collision between the western and eastern blocks of the craton. This may indicate that the lithospheric mantle underlying the NCC has undergone at least two major thinning events.

\section{References}

Becker, H., Horan, M.F., Walker, R.J., Gao, S., Lorand, J.-P., Rudnick, R.L., 2006. Highly siderophile element composition of the Earth's primitive upper mantle: Constraints from new data on peridotite massifs and xenoliths. Geochimica et Cosmochimica Acta, 70, 4528-4550.

Gao S., Rudnick R.L., Carlson, R.W., McDonough, W.F., Liu, Y-S., 2002. Re-Os evidence for replacement of ancient mantle lithosphere beneath the North China Craton. Earth and Planetary Science Letters, 198, 307322.

Handler, M.R., Bennett, V.C., Esat, T.M., 1997. The persistence of off-cratonic lithospheric mantle: Os isotopic systematics of variably metasomatised southeast Australian xenoliths. Earth and Planetary Science Letters, 151, 61-75.

McDonough,W.F., Sun,S.S.,1995. The chemical composition of the Earth. Chemical Geology, 120, 223-253.

Meisel, T., Walker, R.J., Irving, A.J. and Lorand, J-P., 2001. Osmium isotopic compositions of mantle xenoliths: A global perspective. Geochimica et Cosmochimica Acta, 65, 1311-1323.

Wu, F-Y., Walker, R.J., Yang, Y-H., Yuan, H-L,Yang J-H., 2006. The chemical-temporal evolution of lithospheric mantle underlying the North China Craton. Geochimica et Cosmochimica Acta, 70, 5013-5034.

Xu, Y-G., Blusztajn, J., Ma, J-L., Suzuki, K., Liu, J.-F., Hart, S.R., 2008. Late Archean to Early Proterozoic lithospheric mantle beneath the western North China craton: $\mathrm{Sr}-\mathrm{Nd}-\mathrm{Os}$ isotopes of peridotite xenoliths from Yangyuan and Fansi. Lithos, 102, 25-42.

Xu, X., Griffin, W.L., O'Reilly, S.Y., Pearson, N.J., Geng, H., Zheng, J.P.,2008. Re-Os isotopes of sulfides in mantle xenoliths from eastern China: Progressive modification of lithospheric mantle. Lithos, 102, 43-64.

Zhao, G.C., Cawood, P.A., Wilde, S.A., and Sun, M., 2000. Metamorphism of basement rocks in the Central Zone of the North China Craton: implications for Paleoproterozoic tectonic evolution. Precambrian Research, 103, 55-88. 
Zheng, J.P.,1999. In:Mesozoic-Cenozoic mantle replacement and lithospheric thinning beneath the eastern China, China University of Geosciences Press, p. 126. 